\title{
TOEING THE Line: THE DELICATE BALANCE ATTORNEYS MUST MAINTAIN WHEN RESPONDING TO AUDITOR INQUIRY REQUEST LETTERS
}

\author{
R. AleXANDER SWIDER ${ }^{*}$
}

\section{INTRODUCTION}

The Securities and Exchange Commission ("SEC") requires all publicly traded companies to file quarterly and annual financial statements with the SEC. ${ }^{1}$ Before filing these financial statements, a publicly held company must engage a public accounting firm ${ }^{2}$ to opine on the accuracy of the company's statements. ${ }^{3}$ Even those companies that are not publicly traded are often obligated to produce financial reports to prove they are in compliance with lender debt covenant stipulations, ${ }^{4}$ to provide management with key financial indicators to help make operational decisions, and to allow potential investors to make informed decisions

* J.D. Candidate, 2017, Indiana University Robert H. McKinney School of Law; Bachelor of Science, 2011, Indiana University-Bloomington. Mr. Swider is a Certified Public Accountant licensed in Indiana and practiced for nearly three years with a public accounting firm in Indianapolis prior to his study of law. He would like to thank his wife (Hollyn), parents (David and Cynthia), siblings (Joel—who helped come up with the topic of this Note - and Christina), and adopted furry son (Ollie) for lovingly providing support throughout the Note-writing process.

1. Securities Exchange Act of 1934, 17 C.F.R. $§ 240.13 a-13$ (2016) (mandating quarterly reports for publicly traded companies); 17 C.F.R. $\$ 240.13 \mathrm{a}-1$ (mandating annual reports for publicly traded companies).

2. Public accounting firms employ Certified Public Accountants ("CPAs") to audit the financial statements of publicly held companies. CPAs are professionals who have met the requirements set forth by each individual state's board of accountancy. While each state sets its own additional specific requirements, becoming a CPA in all states requires "completing a program of study in accounting at a college or university, passing the Uniform CPA Exam, and obtaining a specific amount of professional work experience in public accounting." FAQs-Become a CPA, Am. Inst. CPAs, http://www.aicpa.org/BecomeACPA/FAQs/Pages/FAQs.aspx [http://perma.cc/3KWF-D5M8] (last visited Mar. 23, 2017). CPAs may serve a variety of roles for their clients, including completing tax work, helping analyze the valuation of a business, IT consulting, and auditing a corporation's financial statements. CPA Career Paths, AM. INST. CPAs, http:/www.aicpa.org/career/careerpaths/pages/default.aspx [https://perma.cc/3FYL-BRKD] (last visited Apr. 21, 2017). When this Note refers to a CPA, accountant, public accountant, or auditor, this Note is referring to a CPA's role as an auditor of a public or private company's financial statements, unless otherwise specified.

3. Investor Publications, U.S. SeC. \& ExChANGE Commission, http://www.sec.gov/ investor/pubs/aboutauditors.htm [http://perma.cc/9W7M-LXZ7] (last visited Mar. 23, 2017).

4. Debt or loan covenants are clauses within lending contracts that impose requirements on the borrower to keep a given financial metric above a specified level. See The Basics of Lending and Loan Covenants, SUNTRUST, https://www.suntrust.com/resourcecenter/article/the-basics-oflending-and-loan-covenants\# [https://perma.cc/9GCR-RPNH] (last visited Apr. 21, 2017). If a metric falls below the agreed-upon level, the lender may call its loan. See id.

http://doi.org/10.18060/4806.1158 
about whether to buy or sell ownership in a given company. ${ }^{5}$ In auditing a company's financial statements, public accounting firms must ensure the financial statements conform to generally accepted accounting principles ${ }^{6}$ ("GAAP") as promulgated by the Financial Accounting Standards Board ("FASB").

As part of the auditing process, accountants request certain information from lawyers regarding their mutual clients. Within an audit legal letter inquiry, a public accountant must request specific information regarding any pending litigation or unasserted claims. ${ }^{7}$ An attorney representing a company, however, is often unwilling to disclose such detailed information for a variety of reasons, including fear of breaching her client's confidentiality and inherent uncertainties in how a court might rule on a given case. ${ }^{8}$ Because of these sometimes contrary objectives, a real discrepancy exists between the nature and extent of the information requested by public accountants and that provided by lawyers.

This Note examines an attorney's dilemma in deciding how to respond to audit inquiry letters. Part I discusses how attorneys' and accountants' perspectives starkly contrast in their respective objectives in information disclosure about their clients. ${ }^{9}$ Auditors owe allegiance to the public as opposed to attorneys, who must maintain confidentiality with respect to sensitive matters and who also must consider the wishes of corporate management. ${ }^{10}$ As a result of these divergent loyalties, this Note first examines why it is inherently difficult to agree on the appropriate level of disclosure requirements regarding pending litigation or unasserted claims. ${ }^{11}$

Part II explains that a gap currently exists between what the FASB requires its public accountants to request from attorneys in the audit legal letter and what the $\mathrm{ABA}$ advises its lawyers to provide in response to these requests. ${ }^{12}$ The second part of this Note also details some of the more significant disconnects and explains how these inconsistencies can lead to confusion and frustration from

5. Video Webcast: Vincent J. Love and John H. Elckemeyer, Accountants' Liability: Litigation and Issues in the Wake of the Financial Crisis - GAAP v. IFRS; Public v. Private Company Accounting; PCAOB AS and GAAS v. ISA (Am. Law Inst. Sept. 15-16, 2011).

6. "The term generally accepted accounting principles (GAAP) has a specific meaning for accountants and auditors. The American Institute of Certified Public Accountants (AICPA) Code of Professional Conduct prohibits members from expressing [opinions about the accuracy of the financial statements] . . if such information contains any departures from [GAAP]." Authoritative Source of Guidance, Fin. ACCT. STANDARDS ADVISORY BOARD, http://www.fasab.gov/accountingstandards/authoritative-source-of-gaap/ [http://perma.cc/88SK-YJRW] (last visited Oct. 5, 2015).

7. Audit Evidence-Specific Considerations for Selected Items: Litigation, Claims, and Assessments-Communication with the Entity's Legal Counsel, Clarified Statements on Auditing Standards, AU-C $\S 501$ 『 .22 (Am. Inst. of Certified Pub. Accountants 2016).

8. M. Eric Anderson, Talking 'Bout My Litigation-How the Attorney Response to an Audit Inquiry Letter Discloses as Little as Possible, 7 Transactions: TenN. J. Bus. L. 143, 143 (2005).

9. See infra Part I.

10. See id.

11. See id.

12. See infra Part II.A-B. 
both accountants and lawyers. ${ }^{13}$

Part III examines a line of cases that addresses the issue of whether information disclosed by the attorney to the public accountant is subject to waiver of the attorney-client privilege and work-product doctrine. ${ }^{14}$ The third part of this Note also provides a few general observations or rules that can be gleaned based on the pattern of how these cases were decided..$^{15}$ In examining the outcomes of these cases, this Note details how the passage of the Sarbanes-Oxley Act of 2002 led to increased audit oversight and more stringent disclosure requirements from attorneys regarding threatened or pending litigation. ${ }^{16}$

Finally, Part IV explains that "courts are currently split with respect to the waiver of privilege upon the disclosure of corporate counsel's legal conclusions to independent auditors." ${ }^{.17}$ Because this circuit split "muddies the waters" when it comes to lawyers deciding how to respond to legal letter requests, the Note proposes two solutions to this current schism. ${ }^{18}$ The first solution involves promulgating a nation-wide accountant-client privilege and the second solution involves revamping practice guidebooks for writing and responding to audit legal letters that incorporate both accountants' and attorneys' perspectives. ${ }^{19}$

\section{EXAmination of the Problem}

A fundamental gulf exists between the roles of lawyers and accountants. This divergence can largely be attributed to lawyers' and accountants' diametrically opposing loyalties, interests, and constituencies. ${ }^{20}$ Public accountants owe their truest allegiance to a client's "creditors and stockholders, as well as the investing public ... [and] [t]his 'public watchdog' function demands that the accountant maintain total independence from the client at all times and requires complete fidelity to the public trust." 21 In contrast, attorneys owe an "unwavering duty of loyalty" to their clients and "have an obligation to their clients to provide competent, diligent, truthful, independent and confidential representation." ${ }^{22}$ As a result of these contrary loyalties, accountants and attorneys have difficulty agreeing on the appropriate level of disclosure required regarding pending litigation or unasserted claims. ${ }^{23}$

13. See infra Part II.C-D.

14. See infra Part III.

15. See id.

16. See id.

17. Aaron J. Rigby, The Attorney-Auditor Relationship: Responding to Audit Inquiries, the Disclosure of Loss Contingencies and the Work-Product Privilege, 35 No. 3 SEC. REG. L.J. ART 1 (2007).

18. See infra Part IV.

19. See id.

20. Rigby, supra note 17.

21. United States v. Arthur Young \& Co., 465 U.S. 805, 818 (1984).

22. Rigby, supra note 17.

23. Anderson, supra note 8, at 166 ("The possibility that an 'expectation gap' exists between 
Because accountants owe their main duty to outside investors and creditors, accountants and the standards they must follow value transparency in every aspect of clients' financial statements: "Transparent, informative and accurate financial reporting are the lifeblood of the capital markets and are essential for investors to make informed decisions as to how to allocate their capital." ${ }^{24}$ To provide the investing public with the most precise information possible, public accountants request substantial information from lawyers regarding loss contingencies, ${ }^{25}$ such as pending litigation and unasserted claims. Auditors request detailed information from attorneys that is necessary to evaluate the following factors within a client's financial statements:

(a) The period in which the underlying cause [(that is, the cause for action) of the pending or threatened litigation or of the actual or possible claim or assessment] occurred[;]

(b) The degree of probability of an unfavorable outcome[;] [and]

(c) The ability to make a reasonable estimate of the amount of loss. ${ }^{26}$

Conversely, because attorneys owe their primary loyalty to their clients, they desire to keep their communications with their clients confidential and disclose the bare minimum to third parties inquiring about a specific case involving their clients. ${ }^{27}$ Both accountants and attorneys have legitimate concerns. There is a host of compelling and severe consequences an attorney or accountant faces when too many or too few details are revealed in response to an audit inquiry letter. ${ }^{28}$

\section{A. The Dangers in Disclosing Too Much to Auditors}

Attorneys have several fears in disclosing too much information to auditors

what the auditor requests and what the attorney provides is quite real.").

24. Steven B. Harris, The Importance of Auditing and Audit Regulation to the Capital Markets, Pub. COMPAny ACCT. Oversight BoArd (Mar. 20, 2014), http://pcaobus.org/ News/Speech/Pages/03202014_American.aspx [perma.cc/X5K3-6UEP].

25. A loss contingency is " $[\mathrm{a}] \mathrm{n}$ existing condition, situation, or set of circumstances involving uncertainty as to possible loss to an entity that will ultimately be resolved when one or more future events occur or fail to occur." Financial Accounting Standards Board, Accounting Standards Codification Glossary (2010) [hereinafter ASC Glossary].

26. Audit Evidence-Specific Considerations for Selected Items: Litigation, Claims, and Assessments, Clarified Statements on Auditing Standards, AU-C $§ 501 \uparrow .17$ (Am. Inst. of Certified Pub. Accountants 2016).

27. Jamie L. Yarbrough, Mind the GAAP: Moving Beyond the Accountant-Attorney Treaty, 92 Tex. L. Rev. 749, 754 (2014).

28. Anderson, supra note 8, at 143-44 (describing a variety of reasons attorneys are reluctant to disclose key information in a response to an audit letter inquiry, including fear of betraying a client's confidences and trepidation about a client's adversarial party gaining leverage in subsequent court proceedings through exposure of counsel's evaluation of a client's liability in specific litigation). 
in response to auditors' legal letters, none of which are unfounded. Among the most serious reservations attorneys have in disclosing information to accountants is the concern that providing information to an auditor about a client might waive the attorney-client privilege. ${ }^{29}$ The attorney-client privilege is a fundamental principle that encourages clients to openly discuss their legal issues with attorneys with confidence that the client's complete confidentiality will be maintained. ${ }^{30}$ Furthermore, the privilege enriches legal compliance, improves the justice system's efficacy, and augments one's constitutional rights. ${ }^{31}$ Because the attorney-client privilege is the "backbone of the legal profession," 32 it is no wonder that attorneys are cautious not to disclose too much information that might result in waiver of the privilege.

An additional crucial implication of disclosing too much to a public accountant during an audit is the potential of waiving work-product doctrine protections. ${ }^{33}$ The work-product doctrine shields from discovery a lawyer's thoughts, mental impressions, and private memoranda while equipping for trial. ${ }^{34}$ Lawyers fear that waiving this privilege would provide fodder to future prospective plaintiffs who may sue the attorney's client. ${ }^{35}$ Because " $[\mathrm{t}]$ he lawyer's duty is to the client and is private in nature, ${ }^{, 36}$ providing ammunition to future plaintiffs against a lawyer's client is a risk many lawyers are understandably unwilling to take. As detailed by a series of cases in Part III of this Note, attorneys have good reason to fear potentially waiving attorney-client privilege and the work product doctrine through disclosures to independent auditors.

Furthermore, an attorney might apprehend that disclosing too much information about a client's pending or unasserted litigation may considerably weaken the chances that the client would be willing and able to communicate confidentially in alternative circumstances. ${ }^{37}$ Damaging a client's perceived or

29. W.R. Koprowski et al., Financial Statement Reporting of Pending Litigation: Attorneys, Auditors, and Differences of Opinions, 15 FordHAM J. CORP. \& Fin. L. 439, 448 (2010) ("[T]he [attorney-client] privilege may be waived if the privileged communications are made available to a third party outside the attorney-client relationship.").

30. Id. at 447-48.

31. ABA Task Force on the Attorney-Client Privilege, Report of the American Bar Association's Task Force on the Attorney-Client Privilege, 60 Bus LAw. 1029, 1037 (2005).

32. Jackie Unger, Maintaining the Privilege: A Refresher on Important Aspects of the Attorney-Client Privilege, AM. B. Ass'N, http://www.americanbar.org/publications/blt/2013/10/01_ unger.html [http://perma.cc/S8AF-32UU] (last visited Mar. 25, 2017).

33. Koprowski et al., supra note 29, at 450 ("Like the attorney-client privilege, the work product protection is subject to waiver, but on a more limited basis.").

34. Rigby, supra note 17.

35. Id.

36. John W. Allen, Walking Through the Minefield-Ethical and Liability Risks in Auditor Response Letters, 77-JAN. FLA. B. J. 10, 10 (2003).

37. Am. Bar Ass'n, Statement of Policy Regarding Lawyers' Responses to Auditors' Requests for Information (1975), in AM. BAR Ass'N, AUdiTOR's LETTER HANDBOOK pmbl. (2003) [hereinafter ABA Statement of Policy]. 
actual attorney-client confidentiality can lead to "the risk that corporations and board committees will severely limit the scope of the legal advice they seek, or worse neglect to seek it altogether." ${ }^{38}$ Such a result is troubling as our society is "structurally and legally complex," which makes competent legal guidance indispensable. ${ }^{39}$

Another concern lawyers face when responding to audit inquiry letters is that adversaries in lawsuits might gain an advantage in settlement negotiations if an attorney discloses the amount or range of potential loss from the ongoing civil action. $^{40}$

[A]n opponent in litigation can potentially gain access to significant information about the assessments of an enterprise, its auditor, and its attorney about the enterprise's exposure in the litigation, potentially evidenced by amounts that the enterprise has already accrued as an expense, but not yet paid, related to the underlying litigation. ${ }^{41}$

Furthermore, in pretrial negotiations, a public company's disclosure of litigation "in its financial statement footnotes or within the 'Management's Discussion and Analysis' portion of its SEC filings may reveal the amount for which it would be willing to settle or the amount for which it already has provided as a reserve against its profits. ${ }^{42}$ While disclosing too much to an auditor regarding pending or threatened litigation presents some seriously negative implications, there is also an assortment of issues that underlie providing too few details in response to an auditor's request.

\section{B. The Harm in Disclosing Too Little in Response to Auditors}

If a lawyer refuses to provide material that a public accountant requests in her inquiry letter, a scope limitation ${ }^{43}$ of the auditor's examination could preclude the

38. Rigby, supra note 17.

39. ABA Task Force on the Attorney-Client Privilege, supra note 31, at 1037-38.

40. Matthew J. Barrett, Opportunities for Obtaining and Using Litigation Reserves and Disclosures, 63 Оніо ST. L.J. 1017, 1103 (2002).

41. Id.

42. James S. Johnson, The Accountable Attorney: A Proposal to Revamp the ABA's 1976 Statement of Policy Regarding Lawyers' Responses to Auditors' Requests for Information, 14 TEX. WESLEYAN L. REV. 27, 45 (2007).

43. An auditor can only express an opinion about the accuracy of a company's financial statements if she has been able to conduct all the proper procedures and collect all the audit evidence she deems necessary under the circumstances. Modifications to the Opinion in the Independent Auditor's Report: Circumstances When a Modification to the Auditor's Opinion Is Required-Nature of an Inability to Obtain Sufficient Appropriate Audit Evidence, Clarified Statements on Auditing Standards, AU-C $\S 705$ ๆ .A8-.A12 (Am. Inst. of Certified Pub. Accountants 2016). Any restrictions on an audit's scope, such as an inability to obtain adequate accounting records or supporting audit evidence for a specific balance sheet or income statement item, is referred to as a "scope limitation." See id. 
public accountant from issuing a clean (unmodified) opinion. ${ }^{44}$ An attorney unquestionably wants to avoid triggering the auditor to issue a qualified opinion because the prospect a qualified audit opinion or no audit opinion at all "is completely untenable given the financial markets' immediate and devastating reaction to anything short of unqualified audit opinions in the post-Enron world. ${ }^{45}$ These potentially devastating effects could include negatively affecting a corporation's power to draw investors, obtain loans, and even operate a financially-viable business. ${ }^{46}$

Additionally, not disclosing enough information concerning pending litigation fails to provide stockholders, prospective investors, and the public-atlarge with enough information regarding the financial state of the company. Texaco, Inc. v. Pennzoil Co. is an example of how lack of disclosure regarding pending litigation can lead to disastrous consequences for investors. ${ }^{47}$ In Texaco, Pennzoil sued Texaco, alleging that Texaco had tortiously interfered with a merger agreement between Pennzoil and Getty Oil. ${ }^{48}$ The jury awarded Pennzoil $\$ 10.53$ billion in damages ${ }^{49}$ and eventually forced Texaco into bankruptcy protection. ${ }^{50}$

In its disclosure to investors, Texaco did not accrue a single dollar of loss throughout the entire contentious legal battle. ${ }^{51}$ While Texaco disclosed the existence of a lawsuit by Pennzoil in its public report that immediately preceded the judgment, Texaco underestimated the potential impact the litigation would have on the financial stability of the company, stating: "While it is impossible to ascertain the ultimate legal and financial liability ... the aggregate amount of such liability is not anticipated to be materially important in relation to the consolidated financial position of the Company and its subsidiaries." ${ }^{52}$ This loss estimation was grossly deficient and ultimately cost the company and its investors severely.

Kinetic Concepts, Inc. v. Hillenbrand Industries, Inc. ${ }^{53}$ is another example of

44. An "unmodified opinion" is "The opinion expressed by the auditor when the auditor concludes that the financial statements are presented fairly, in all material respects, in accordance with the applicable financial reporting framework." Forming an Opinion and Reporting on Financial Statements: Definitions, Clarified Statements on Auditing Standards, AU-C § 700 $\mid .11$ (Am. Inst. of Certified Pub. Accountants 2016). A modified opinion includes "a qualified opinion, an adverse opinion, or a disclaimer of opinion.” Scope of this Section, AU-C § 700 ๆ 03.

45. Amicus Brief of the Association of Corporate Counsel ("ACC") in Support of Relators' Petition for Writ of Mandamus and Brief on the Merits at *8, No. C2002459, In Re Stone \& Webster, Inc., 2006 WL 655043 (Tex. Jan. 27, 2006) (No. 05-0552).

46. Barrett, supra note 40, at 1032.

47. See generally 729 S.W.2d 768 (Tex. App. 1987).

48. Id. at 784 .

49. Id.

50. Yarbrough, supra note 27, at 756-57.

51. Id. at 757.

52. Texaco Inc., 1984 Annual Report, at Note 16 (1985).

53. 262 F. Supp. 2d 722 (W.D. Tex. 2003). 
inadequate disclosures of pending litigation and the negative impact on stockholders. Kinetic Concepts sued Hillenbrand for antitrust violations in conjunction with Hillenbrand's hospital bed marketing. ${ }^{54}$ Hillenbrand settled for $\$ 250$ million despite recording no loss provision relative to damages sought by Kinetic Concepts. ${ }^{55}$ In the wake of such a costly lawsuit settlement, Hillenbrand stockholders no doubt lost large profits, but also likely lost confidence in the company's integrity in its presentation of its financial statements.

Moreover, there is an omnipresent threat of exposure of a client and attorney to securities law violations when an attorney fails to divulge material facts to a public accountant during an audit. ${ }^{56}$ For accountants and lawyers working with public companies, there is serious danger of violating the antifraud provisions of the federal securities act, SEC Rule 13b2-2(b). ${ }^{57}$ SEC Rule 13b2-2(b) proscribes attorneys from providing "an auditor with an inaccurate or misleading legal analysis." "The "Tuality and usefulness of attorney responses to audit inquiries is suspect at best. One commentator has suggested that '[i]n most instances, the auditor could ... obtain more information just by reviewing the pleadings filed at the local courthouse.", 59

As the result of the competing interests discussed above, the current system of disclosure is failing to provide transparency. One of the principal objectives of the SEC's disclosure requirements is to afford current and prospective shareholders the opportunity to make informed investment decisions based on companies' financial information. ${ }^{60}$ Currently, however, the framework through which corporations report contingent liabilities fails to provide this ideal in a multitude of ways. ${ }^{61}$

\section{CurRent Authoritative Guidance And InConsistencies Among Them}

\section{A. Financial Accounting Standards Board ("FASB")}

The FASB's Accounting Standards Codification ${ }^{62}$ requires disclosure of loss contingencies. A loss contingency is defined as "[a]n existing condition, situation, or set of circumstances involving uncertainty as to a possible loss to an entity that will ultimately be resolved when one or more future events occur or fail to

54. Id. at 722 .

55. Id. at 725 .

56. Marc I. Steinberg, The Corporate/Securities Attorney as a "Moving Target"-Client Fraud Dilemmas, 46 WASHBURN L.J. 1, 22 (2006).

57. Id.

58. Improper Influence on Conduct of Audits, Exchange Act Release No. 34-47890, 2003 WL 21148349 (May 20, 2003).

59. Yarbrough, supra note 27, at 753 (quoting Anderson, supra note 8, at 144).

60. ${ }^{I d}$.

61. Id.

62. The Accounting Standards Codification [hereinafter ASC] is FASB's authoritative guide to GAAP. 
occur." ${ }^{93}$ Loss contingencies that must be disclosed within the financial statements include pending or threatened litigation and actual or possible claims and assessments. ${ }^{64}$

Because "[a]n auditor ordinarily does not possess legal skills and, therefore, cannot make legal judgments," public accountants send audit legal letters to those attorneys with whom the client's management conferred during the fiscal year. ${ }^{65}$ Within an audit legal letter inquiry, a public accountant must request specific information regarding any pending litigation or unasserted claims ${ }^{66}$ including "[a] description of the nature of the matter, the progress of the case to date, and the action the company intends to take (for example, to contest the matter vigorously or to seek an out-of-court settlement). ${ }^{, 67}$ Additionally, the auditor's inquiry letter asks the attorney to evaluate the probability of an adverse conclusion to a pending or threatened lawsuit and, if possible, the specific loss amount or a range of the potential loss. ${ }^{68}$

\section{B. American Bar Association ("ABA")}

The ABA developed guidelines ${ }^{69}$ for responding to audit inquiry letters on December 8, 1975, called the ABA Statement of Policy Regarding Lawyers' Responses to Auditors' Requests for Information (the "ABA Statement"). ${ }^{70}$ The ABA developed the ABA Statement to act as a "grand compromise or treaty" between attorneys and certified public accountants (CPAs). ${ }^{71}$ The ABA Statement intends to assist lawyers in providing loss contingency information to public

63. Loss contingency, ASC Glossary (2010).

64. ASC 450-20 (2010).

65. Audit Evidence-Specific Considerations for Selected Items: Litigation, Claims, and Assessments-Communication with the Entity's Legal Counsel, Clarified Statements on Auditing Standards, AU-C $\S 5019$.A46 (Am. Inst. of Certified Pub. Accountants 2016).

66. See Understanding Attorneys' Responses to Auditors' Inquiries, FreE LIBR., http://www.thefreelibrary.com/Understanding+attorneys'+responses+to+auditors'+inquiries.a011475622 [http://perma.cc/W8YZ-SW5G] (last visited Mar. 26, 2017) (“Unasserted claims arise when events have occurred that may give rise to legal liability but no litigation has actually been initiated or threatened or settlement proposed. For example, a company might manufacture a product that injures consumers over time. This is an unasserted claim until the injuries are discovered and legal action initiated.").

67. Audit Evidence-Specific Considerations for Selected Items: Litigation, Claims, and Assessments-Communication with the Entity's Legal Counsel, Clarified Statements on Auditing Standards, AU-C $\S 501$ ๆ .22 (Am. Inst. of Certified Pub. Accountants 2016).

68. Id.

69. Since the ABA Statement is merely a guide, attorneys are not required to abide by it. Anderson, supra note 8, at 150 .

70. ABA Statement of Policy, supra note 37.

71. Byron F. Egan et al., How to Respond to Audit Letters 1 (State Bar of Tex. CLE Tel. Seminar, July 29, 2005), http://images.jw.com/com/publications/503.pdf[https://perma.cc/PQ8HWPX5]. 
accountants in their preparation of a client's financial statements while, in the process, minimizing the chance of compromising the attorney-client privilege. ${ }^{72}$

While the ABA Statement attempts to balance the interests of both accountants and attorneys, its top priority is to conserve the attorney-client privilege and the work product doctrine. ${ }^{73}$ This fact has led some to conclude that the ABA Statement is inconsequential when it comes to assisting public accountants accomplish their disclosure objectives. ${ }^{74}$ The ABA Statement contains "a Preamble that comes across as both cautionary and defensive." 75 The Preamble begins by emphasizing the importance of the attorney-client privilege: "The public interest in protecting the confidentiality of lawyer-client communications is fundamental." ${ }^{, 76}$ It goes on to warn of the potential harm that may befall the lawyer who discloses too much information about his client to the public accountant. ${ }^{77}$ The ABA Statement cautions that merely divulging the contents of lawyer/client communications to an outside auditor, even after obtaining client consent, may "significantly impair the client's ability in other contexts to maintain the confidentiality of such communications."

The ABA Statement recognizes that a client's attorney may be the most reliable source from whom to obtain a narrative regarding claims asserted against the client; whether the client plans to deny, contest, or admit specific pending allegations; and the degree of exposure a client faces in a litigation matter. ${ }^{79}$ Additionally, the ABA Statement acknowledges the importance of having accurate and complete financial statements on which stockholders can rely. ${ }^{80}$ However, the Preamble is explicit that this public policy consideration must not undercut or weaken the attorney's relationship with his client. ${ }^{81}$

The ABA Statement advises counsel against expressing judgment regarding whether an attorney forecasts an adverse result in a particular pending lawsuit unless the predicted outcome is "probable" or "remote." 82 In regard to an unasserted claim, "where a potential claimant has not manifested an awareness of the potential claim, ${ }^{, 83}$ disclosure is only compulsory if the client concludes "(i)

72. Id.

73. Id. at 54; ABA Statement of Policy, supra note 37.

74. See Egan et al., supra note 71.

75. Anderson, supra note 8 , at 150.

76. ABA Statement of Policy, supra note 37.

77. $I d$.

78. $I d$.

79. $I d$.

80. Id. ("It is also recognized that our legal, political and economic systems depend to an important extent on public confidence in published financial statements. To meet this need the accounting profession must adopt and adhere to standards and procedures that will command confidence in the auditing process.").

81. Anderson, supra note 8, at 151 (citing ABA Statement of Policy, supra note 37).

82. ABA Statement of Policy, supra note 37, at para. 5.

83. Marc I. Steinberg, Attorney Liability After Sarbanes-Oxley $§ 3.06$ (2005) (citing ABA Statement of Policy, supra note 37, at para. 5). 
it is probable that a claim will be asserted, (ii) there is a reasonable possibility, if the claim is in fact asserted, that the outcome will be unfavorable, and (iii) the liability resulting from such unfavorable outcome would be material to [the company's] financial condition. ${ }^{" 84}$ Because the ABA Statement allows the client to make the ultimate decision to divulge contingent liabilities, nondisclosure is the most probable result. ${ }^{85}$

\section{Securities and Exchange Commission ("SEC")}

The Sarbanes-Oxley Act of 2002 ("SOX") was promulgated in response to a variety of corporate governance scandals, including those that occurred at Enron Corp. and WorldCom Inc. ${ }^{86}$ "“[T]he Sarbanes-Oxley-created environment has upset the harmony between required disclosure to auditors and the ... workproduct privilege' and has threatened to severely affect the fragile balance enjoyed for nearly thirty years between auditors and attorneys regarding their responses to audit inquiry letters." ${ }^{87}$ SOX established the Public Company Accounting Oversight Board ("PCAOB"), which is a privately run, non-profit corporation whose mission is to regulate and supervise public company auditors and their conduct. ${ }^{88}$ While the $\mathrm{PCAOB}$ performs a critical role in helping regulate the public accounting industry, the PCAOB's stance on requiring detailed documentation in calculating and disclosing contingencies threatens to negatively affect the relationship between CPAs and corporate lawyers. ${ }^{89}$

Since Congress' passage of SOX, lawyers face a more uncertain landscape when it comes to how they choose to balance their responsibility to accurately report client information to inquiring auditors while remaining loyal to their

84. Steinberg, supra note 56, at 23 (quoting ABA Statement of Policy, supra note 37, at para. 6 n.3).

85. $I d$.

86. Investigators revealed in the fall of 2001 that Enron had misrepresented its earnings and management embezzled money from the firm. Rosemary Peavler, The Sarbanes-Oxley Act and the Enron Scandal-Why Are They Important?, ABout Money (Dec. 16, 2014), http://bizfinance. about.com/od/smallbusinessfinancefaqs/a/sarbanes-oxley-act-and-enron-scandal.htm [http://perma.cc/3XDA-8QGV]. "Eventually, the company went bankrupt because of fraudulent earnings reports and embezzlement. This was quite a shock to the American financial system as Enron was seen as one of the top companies in the U.S." Id. WorldCom perpetrated fraud, making "\$3.8 billion in questionable accounting entries that had the effect of inflating WorldCom's earnings." Greg Farrell, WorldCom's Whistle-Blower Tells Her Story, ABC NEws (Feb. 15, 2008), http://abcnews.go.com/Business/story?id=4295223\&page=1 [http://perma.cc/8E84-SUDH]. "The company filed for bankruptcy protection, wiping out its shareholders, and the public demanded immediate action. Congress complied, passing the law known as the Sarbanes-Oxley Act." Id.

87. Rigby, supra note 17 (quoting Peggy A. Heeg, Auditors are Increasingly at Odds with Attorneys, NAT'L L.J. (2006)).

88. Id.

89. Id. 
publicly traded clients. ${ }^{90}$ Specifically, attorneys must navigate through $\S \S 303$ and 307 of the Sarbanes-Oxley Act of 2002, which increases attorney tensions when responding to audit inquiry requests. ${ }^{91}$ Section 303 directed the SEC to adopt rules to implement $\S 303$ (a) "to ensure that management makes open and full disclosures to, and has honest discussions with, the auditor of the issuer's financial statements. ${ }^{, 92}$ In response to the directive, the SEC issued Rule 13b22(b)(1), which provides:

No officer or director of an issuer, or any other person acting under the direction thereof [i.e., the attorney], shall directly or indirectly take any action to coerce, manipulate, mislead, or fraudulently influence any independent public or certified public accountant engaged in the performance of an audit or review of the financial statements of that issuer that are required to be filed with the Commission pursuant to this subpart or otherwise if that person knew or should have known that such action, if successful, could result in rendering the issuer's financial statements materially misleading. ${ }^{93}$

In its comments upon releasing this rule, the SEC specifically mentioned that "[p]roviding an auditor with inaccurate or misleading legal analysis" is an example of "actions that improperly influence an auditor" and could result in an auditor rendering materially misleading financial statements. ${ }^{94}$

SOX $\S 307$ discusses standards of professional conduct, mandating the SEC to adopt rules of professional responsibility for attorneys representing public companies before the SEC. ${ }^{95}$ These rules address attorney reporting requirements when lawyers are aware of misconduct committed by a publicly traded client's officers, directors, or employees. ${ }^{96}$ The rules contained in Part 205 of the Code of Federal Regulations require that an attorney report up the chain of command within the company when an attorney has "evidence of a material violation" of securities laws or breach of fiduciary duty or similar violations by the public company. ${ }^{97} \mathrm{SOX} \S 307$ does not specifically discuss an attorney's duty to disclose loss contingencies and how $\S 307$ might affect the work-product doctrine; however, "it does evidence a position regarding confidentiality and privileges that is different than that embraced and respected when the [ABA Statement] was

90. Id.

91. Steinberg, supra note 56 , at 23.

92. Improper Influence on Conduct of Audits, Exchange Act Release No. 34-47890, 2003 WL 21148349 (May 20, 2003).

93. Securities Exchange Act of 1934, 17 C.F.R. $\S 240.13 b 2-2(b)(1)$ (2016) (emphasis added).

94. Improper Influence on Conduct of Audits, Exchange Act Release No. 34-46685, 2002 WL 31356568 (Oct. 18, 2002).

95. See 17 C.F.R. $\S 205$.

96. Rigby, supra note 17.

97. Implementation of Standards of Professional Conduct for Attorneys, Exchange Act Release Nos. 33-8185; 34-47276, 2003 WL 193527 (Jan. 29, 2003). 
[published]." 98

Further, in May 2004, the Deputy Chief Accountant of the SEC gave a speech reflecting the SEC's stance on disclosure of loss contingencies. ${ }^{99}$ The part specifically dealing with pending litigation stated:

Vague or overly broad disclosures that speak merely to litigation, tax, or other risks in general, without providing any information about the specific loss contingencies being evaluated are not sufficient. Registrants and their auditors and attorneys should be critically assessing the claims against the company, and registrants should provide disclosures that discuss the nature of the claim, and the possible range of losses for any claim where the maximum reasonably possible loss is material. ... I find it somewhat surprising the number of instances where zero is considered the low end of a range with no number more likely than any other right up until a large settlement is announced. Interestingly, these situations are also often the ones for which no significant disclosure has been made in the financial statement before the settlement is announced. ${ }^{100}$

These comments reflect the SEC's push for greater transparency in lawyers' responses to auditors' inquiries ${ }^{101}$ and the skepticism surrounding instances in which lawyers fail to provide a possible range of losses for a particular claim.

\section{Discrepancies}

A conflicting set of professional standards guides accountants and lawyers. ${ }^{102}$ With respect to the disclosure of contingent liabilities, "the accounting and auditing standards that guide auditors and the professional standards that guide attorneys have been at odds for the past thirty years." 103 Determining the likelihood that a particular claim will result in a loss is one such discrepancy between the respective standards by which each professional is expected to abide. ${ }^{104}$

Attorneys and CPAs agree that pending or threatened lawsuits should be accrued for ${ }^{105}$ when an unfavorable outcome to the company is "probable" and

98. Rigby, supra note 17.

99. Former Deputy Chief Accountant Scott A. Taub, Sec. \& Exch. Comm'n Office of the Chief Accountant, Remarks at the University of Southern California Leventhal School of Accounting SEC and Financial Reporting Conference (May 27, 2004).

100. Id.

101. Johnson, supra note 42 , at 34 .

102. Accountants' professional guideline relevant to pending litigation is ASC 450 - Accounting for Contingencies (which is the successor to the Statement of Financial Accounting Standards No. 5). Lawyers' professional guideline relevant to pending litigation is the ABA Statement of Policy, supra note 37.

103. Koprowski et al., supra note 29, at 439.

104. Barrett, supra note 40, at 1058.

105. In this context, "accrued for" means charged as a reduction to income, which directly 
when the range or specific dollar amount can be "reasonably estimated."106 However, both professions define quite differently the term "probable" and the phrase "reasonably estimated." 107 The ABA Statement utilizes the word probable when "the prospects of the claimant not succeeding are judged to be extremely doubtful." $" 108$ The FASB, on the other hand, defines probable as " $[\mathrm{t}]$ he future event or events are likely to occur." 109 Therefore, the ABA's Statement "requires a higher degree of certainty about the claimant's chances of success than does the FASB before an asserted claim will be accrued as a charge to income."

Moreover, lawyers can stifle an attempt by auditors to accrue an expense by asserting that it is impossible to reasonably estimate the amount of the loss. ${ }^{111}$ The ABA Statement demonstrates its resistance to disclosing an estimate of potential loss to an auditor by declaring:

[T] he amount or range of potential loss will normally be as inherently impossible to ascertain, with any degree of certainty, as the outcome of the litigation. Therefore, it is appropriate for the lawyer to provide an estimate of the amount or range of potential loss (if the outcome should be unfavorable) only if he believes that the probability of inaccuracy of the estimate of the amount or range of potential loss is slight. ${ }^{112}$

Cementing the point, the Commentary to the ABA Statement also states, "[I]n most situations, an unfavorable outcome will be neither 'probable' nor 'remote' as defined in the Statement of Policy." "113 In effect, the Commentary to the ABA Statement is saying that providing conclusions to a CPA regarding the result of pending lawsuits is, in most circumstances, unnecessary. ${ }^{114}$

In addition to the ABA and the FASB utilizing inconsistent conceptions of probable outcome and reasonably estimated damages (which effectively results in the ABA advising against accruing loss contingencies in instances where the FASB would require accrual), the ABA and the FASB differ in their approaches to defining "reasonable possibility" when there are loss contingencies that are not accrued, but should be disclosed. ${ }^{115}$ When a loss contingency from pending or

decreases net profits. See ASC 450-20-25-2 (2010).

106. Attorney Responses to Audit Letters: The Problem of Disclosing Loss Contingencies Arising from Litigation and Unasserted Claims, 51 N.Y.U. L. REV. 838, 874 (1976) [hereinafter Attorney Responses to Audit Letters].

107. Compare ABA Statement of Policy, supra note 37, at para. 5, with ASC 450-20-25-1 (2010).

108. ABA Statement of Policy, supra note 37, at para. 5 (emphasis added).

109. Probable, ASC Glossary (2010) (emphasis added).

110. Attorney Responses to Audit Letters, supra note 106, at 875.

111. Id.

112. ABA Statement of Policy, supra note 37, at para. 5.

113. Id. at cmt. 5.2.

114. Anderson, supra note 8, at 153.

115. Attorney Responses to Audit Letters, supra note 106, at 876 (citing Financial Accounting Standards Board, Statement of Financial Standards No. 5, 10 (1975), now codified at ASC 450- 
threatened litigation cannot be reasonably estimated, and therefore cannot be accrued, the ABA and the FASB agree that the contingency should still be disclosed in the notes to the financial statements if there is "at least a reasonable possibility that a loss . . . may have been incurred." "However, there is considerable uncertainty over whether public accountants and lawyers harmonize on the definition and application of the operative term "reasonable possibility." 117

The FASB's definition of reasonable possibility is, "The chance of the future event or events occurring is more than remote but less than likely." ${ }^{\prime 18}$ Because the FASB defines remote as "[ $t]$ he chance of the event or events occurring is slight," 119 the FASB "employ[s] a 'slight chance' test for determining whether an unfavorable outcome is remote or is a reasonable possibility." ${ }^{120}$ It is not apparent whether the ABA agrees with the slight chance test FASB advocates or requires more substantial certainty that the client will be successful in pending or threatened litigation before attorneys should posit an unfavorable outcome is remote in the attorneys' communication with the auditors. ${ }^{121}$

One can reasonably infer that the ABA requires a higher degree of certainty in measuring remoteness than the FASB. Such a conclusion derives from both the ABA directive that attorneys should normally refrain from predicting the outcome of asserted claims and the ABA definition of reasonable possibility compared with that of the FASB. ${ }^{122}$ The ABA imposes two conditions for a finding that the likelihood of an unfavorable outcome is remote, "extremely doubtful" and "slight"; whereas the FASB's concept of remote has only one qualifying condition, "slight." ${ }^{, 23}$ Having even subtly different standards for determining the likelihood of a loss occurring on any specific claim may be expected to produce conflicting disclosure standards. ${ }^{124}$

\section{Case Law Addressing Potential W Aiver of the Attorney-Client Privilege AND Work-Product Doctrine}

\section{A. Attorney-Client Privilege}

The basic elements of the attorney-client privilege are the following: (1) a communication (2) between privileged persons, such as an attorney, client, or agent (3) made in confidence (4) for the purpose of procuring or offering the

20-50-2).

116. Compare ASC 450-20-50-3 (2010) (emphasis added), with ABA Statement of Policy, supra note 37 , at cmt. 5.1.

117. Attorney Responses to Audit Letters, supra note 106, at 876.

118. ASC 450-20-50-1 n.6 (2010) (emphasis added).

119. Id. at n.5 (emphasis added).

120. Attorney Responses to Audit Letters, supra note 106, at 876.

121. Id. at 877 .

122. Id

123. Id. at 876-77.

124. Barrett, supra note 40 , at 1058. 
client legal assistance. ${ }^{125}$ The purpose of the attorney-client privilege is to "encourage full and frank communication between attorneys and their clients and thereby promote broader public interests in the observance of law and administration of justice." 126 However, the attorney-client privilege can be waived: "With very few exceptions, if privileged materials are disclosed to third parties, the attorney-client privilege is waived and neither the attorney nor client can keep the information from being discovered by adversaries." 127

The case law surrounding the issue of whether the attorney-client privilege protects disclosure of a lawyer's response to an audit inquiry letter is quite consistent: it generally does not. ${ }^{128}$ To fully comprehend the effect that information being divulged to public accountants has on the attorney-client privilege, it is instructive to parse the distinction between two scenarios. ${ }^{129}$ The first situation is where "communication [is] made in confidence for the purpose of obtaining legal advice from the lawyer." 130

In this first scenario, corporate lawyers may engage third parties, including accountants, "in an agent-principal relationship and consult with others as needed in the course of representing the client regarding confidential client information without waiving the attorney-client privilege." ${ }^{\prime 131}$ As the court in United States $v$. Kovel $^{132}$ explained, the attorney-client privilege is held intact when the accountant acts merely as a "translator" between the lawyer and accountant. ${ }^{133}$ The Kovel court acknowledged that, because accounting concepts often are a "foreign language" to lawyers, it can be necessary for counsel to utilize an accountant to interpret a client's complicated tax problem, for example. ${ }^{134}$ A CPA helping clarify an intricate accounting matter does not destroy the privilege any more than a linguist translating French into English to enable the lawyer to provide legal advice to his client. ${ }^{135}$

In the second circumstance, either (a) the third party is not an agent of the lawyer or client; or (b) the advice sought from the independent third party does not constitute legal advice. ${ }^{136}$ Here, courts have regularly held that the distribution

125. Restatement (Third) of the Law Governing Lawyers $\S 68$ (2000).

126. Upjohn Co. v. United States, 449 U.S. 383, 389 (1981).

127. Rigby, supra note 17.

128. Anderson, supra note 8, at 163.

129. Rigby, supra note 17.

130. United States v. Kovel, 296 F.2d 918, 922 (2d Cir. 1961) (emphasis added).

131. Rigby, supra note 17 (emphasis added).

132. In Kovel, a CPA hired by a law firm refused to answer questions by a grand jury investigating the law firm's client for federal income tax violations, on the grounds that the accountant had attorney-client privilege. 296 F.2d at 919. The court held the attorney-client privilege was not destroyed by the presence of the accountant, who was "necessary, or at least highly useful, for the effective consultation between the client and the lawyer." Id. at 919-22.

133. Id. at 921 .

134. Id. at 922 .

135. See id.

136. Rigby, supra note 17. 
of information results in a waiver of the attorney-client privilege. ${ }^{137}$ Because an attorney responding to a third-party public accountant regarding a matter that is not related to legal advice, but instead for the purpose of issuing financial statements, legal letter responses fall into the second set of circumstances described above. As such, "the attorney-client privilege will not protect disclosure of the attorney's response to the audit inquiry letter."138 While the case law is largely in agreement that the attorney-client privilege does not protect an attorney's response to an audit inquiry letter, there is less certainty in respect to whether an audit letter can be sheltered from discovery under a theory of work product doctrine.

\section{B. Work Product Doctrine}

The work product doctrine protects from disclosure an attorney's legal analysis, trial preparation, and thought processes. ${ }^{139}$ What is protected are not the facts regarding a given issue, but rather "the work performed, materials generated and considerations of the lawyers in connection with the investigation and any recommendations to the [client]." ${ }^{, 140}$ The theory behind the work product doctrine is that lawyers should be able to prepare for trial without fearing that their work might be turned over to opposing counsel by way of a discovery request. ${ }^{141}$ While the doctrine was established by the Supreme Court in $1947,{ }^{142}$ it has since been added to the Federal Rules of Civil Procedure. ${ }^{143}$

To qualify for the protection of the work product doctrine, documents must meet two conditions. First, a document must be prepared "in anticipation of litigation or for trial." 144 Second, a document must have been prepared "by or for another party or its representative." 145 Ambiguity in the interpretation of the phrase "prepared in anticipation of litigation" initially led to a split in courts

137. In re Horowitz, 482 F.2d 72, 82 (2d Cir. 1973) (holding the release of information to independent auditors destroyed the attorney-client privilege); United States v. El Paso Co., 682 F.2d 530, 540 (5th Cir. 1982) (holding the revealing of tax information to independent auditors destroyed confidentiality in regard to these documents); First Fed. Sav. Bank of Hegewisch v. United States, 55 Fed. Cl. 263, 269 (2003) ("Just as documents transmitted to an agent for the preparation of a tax return are not privileged, documents transmitted to an agent for the preparation of an audited financial statement likewise are not privileged.").

138. Anderson, supra note 8, at 163.

139. Koprowski et al., supra note 29, at 448.

140. David M. Brodsky, Updates on the Corporate Attorney-Client Privilege, 8 SEDONA Conf. J. 89, 91 (2007).

141. Koprowski et al., supra note 29, at 449 (citing Hickman v. Taylor, 329 U.S. 495, 511 (1947)).

142. Hickman, 329 U.S. at 514 (holding the discovery of a lawyer's interview notes and related memoranda was prohibited when prepared in anticipation of litigation).

143. FED. R. Civ. P. 26(b)(3).

144. FED. R. Civ. P. 26(b)(3)(A).

145. Id. 
regarding whether audit inquiry letters should receive work product protection. ${ }^{146}$ While the recent trend of cases have largely absolved this fissure, ${ }^{147}$ there remains disagreement regarding another issue: whether disclosing information to an independent auditor constitutes disclosing information to an "adversary," which would waive the work product doctrine. ${ }^{148}$

1. Interpreting the Phrase "In Anticipation of Litigation."-Under the "primary purpose" approach, a document is considered to have been prepared in anticipation of litigation only in the case that the "primary motivating purpose behind the creation of the document was to aid in possible future litigation."149 Under the second, broader approach, the "because of" formulation, a document is considered to have been prepared in anticipation of litigation if the document was "prepared or obtained because of the prospect of litigation."150

Courts originally diverged in respect to whether they would consider a lawyer's response deemed to be prepared in anticipation of litigation, and thus eligible for the work product doctrine privilege. ${ }^{151}$ However, as the acceptance of the broader "because of" approach garnered favor among a growing number of courts, litigation surrounding this issue has dwindled. ${ }^{152}$ The result of the large-

146. Compare United States v. Arthur Young \& Co., No. 84-C-606-B, 1984 U.S. Dist. LEXIS 22991, at*12 (N.D. Okla. Oct. 5, 1984) (holding an audit legal letter was protected by the work product doctrine because it was created in anticipation of litigation), and Tronitech, Inc. v. NCR Corp., 108 F.R.D. 655, 656 (S.D. Ind. 1985) (same), with United States v. Gulf Oil Corp., 760 F.2d 292, 297 (Temp. Emer. Ct. App. 1985) (holding an audit legal letter was not protected by the work product doctrine because the letter was prepared only for the business purpose of preparing the financial statements to comply with the federal securities laws, not in anticipation of litigation).

147. See infra Part III.B.1.

148. See Niagara Mohawk Power Corp. v. Stone \& Webster Eng'g Corp., 125 F.R.D. 578, 587 (N.D.N.Y. 1989) (“[T] he work product protection is waived when documents are voluntarily shared with an adversary or when a party possessing the documents seeks to selectively present the materials to prove a point, but then attempts to invoke the privilege to prevent an opponent from challenging the assertion.").

149. United States v. Adlman, 134 F.3d 1194, 1198 (2d Cir. 1998).

150. Id. at 1202 .

151. Compare Tronitech, 108 F.R.D. at 656 (holding the audit letter was protected by the work product privilege: "An audit letter is not prepared in the ordinary course of business but rather arises only in the event of litigation. It is prepared because of the litigation, and it is comprised of the sum total of the attorney's conclusions and legal theories concerning that litigation.") (emphasis added), with Gulf Oil Corp., 760 F.2d at 297 (holding an audit inquiry letter does not merit work product protection because the primary purpose of the audit inquiry letter was to prepare for the business purpose of readying the financial statements).

152. The following eight circuit courts have adopted the "because of" approach: In re Grand Jury Subpoena, 357 F.3d 900, 907 (9th Cir. 2004) (adopting the "because of" formulation in interpreting the phrase "in anticipation of litigation"); Maine v. U.S. Dep't of Interior, 298 F.3d 60, 68 (1st Cir. 2002) (same); Adlman, 134 F.3d at 1202 (same); Nat'l Union Fire Ins. Co. v. Murray Sheet Metal Co., 967 F.2d 980, 984 (4th Cir. 1992) (same); Senate of P.R. v. U.S. Dep't of Justice, 823 F.2d 574, 586 n. 42 (D.C. Cir. 1987) (same); Simon v. G.D. Searle \& Co., 816 F.2d 397, 401 
scale acceptance of the "because of" methodology is that documents are extended the work product doctrine protection "if the documents contain an estimate of the likelihood of success in litigation or discusses litigation strategies." 153

2. Disclosing Information to an "Adversary."-An additional issue courts have addressed when considering whether a response to an audit legal letter should be protected by the work product doctrine is whether disclosing information to an independent auditor constitutes disclosing information to an "adversary," which would waive the work product doctrine. ${ }^{154}$

While this issue has not yet appeared before a federal circuit court, federal district courts are split in addressing it. In the case, In re Pfizer Inc. Securities and Exchange Litigation, a class action lawsuit was brought against Pfizer Inc. and several of the company's officers for alleged violations of Rule $10 \mathrm{~b}-5^{155}$ of the Securities Exchange Act of $1934 .{ }^{156}$ The plaintiffs asserted the company disclosed legal documents to its independent auditors that understated Pfizer's potential liabilities caused by the sale of 86,000 defective mechanical heart valves. ${ }^{157}$ In response to the plaintiffs' discovery request for these documents, Pfizer argued that the legal documents were protected by the work product doctrine since they contained Pfizer attorneys' thoughts, conclusions, and impressions regarding the accrual reserve for the defective medical devices. ${ }^{158}$

The plaintiffs rebutted this argument by claiming Pfizer waived the work product protection to these documents by disclosing them to its independent auditors, who the plaintiffs argued were "adversaries." 159 The court sided with Pfizer and determined the company's auditors were "not adversaries because they 'obviously' shared a 'common interest' in the information." ${ }^{160}$ While the court did not clarify the specific common interest the auditor and Pfizer shared, the court described how Pfizer's disclosure to its auditors posed no significant danger of the documents being disclosed to a potential adversary. ${ }^{161}$

The court in Medinol Limited v. Boston Scientific Corporation, however, held

(8th Cir. 1987) (same); Binks Mfg. Co. v. Nat'1 Presto Indus., Inc., 709 F.2d 1109, 1118-19 (7th

Cir. 1983) (same); In re Grand Jury Proceedings, 604 F.2d 798, 803 (3d Cir. 1979) (same).

153. Koprowski et al., supra note 29, at 449-50 (citing Adlman, 134 F.3d at 1200).

154. See Niagara Mohawk Power Corp. v. Stone \& Webster Eng'g Corp., 125 F.R.D. 578, 587 (N.D.N.Y. 1989) (stating voluntarily sharing documents with an adversary waives the work product protection for those documents).

155. Rule 10b-5 of the Securities Exchange Act of 1934 outlaws employment of manipulative and deceptive devices.

156. In re Pfizer Inc. Sec. Litig., No. 90 Civ. 1260, 1993 U.S. Dist. LEXIS 18215, at*1-2 (S.D.N.Y. Dec. 22, 1993).

157. Id. at *3.

158. Id. at *6.

159. Id. at *7-8.

160. Ricardo Colón, Caution: Disclosures of Attorney Work Product to Independent Auditors May Waive the Privilege, 52 Loy. L. REv. 115, 128 (quoting In re Pfizer Inc., 1993 U.S. Dist. LEXIS 18215, at *21-22).

161. In re Pfizer Inc., 1993 U.S. Dist. LEXIS 18215, at*21. 
quite differently than did the Pfizer court. In Medinol, the biotechnology company, Boston Scientific, hired an outside attorney to investigate a medical licensing agreement violation. ${ }^{162}$ The outside counsel reported his findings orally during a board of directors meeting. ${ }^{163}$ Independent auditors requested the board minutes during Boston Scientific's financial statement audit as part of the public accountant's standard auditing procedures. ${ }^{164}$

When Medinol Limited sought production of the board minutes, Boston Scientific claimed the documents were protected by the work product doctrine. ${ }^{165}$ In response to this argument, Medinol averred Boston Scientific waived this protection through disclosing this information to adversaries by showing the documents to the company's independent auditors. ${ }^{166}$ The court agreed with Medinol, acknowledging its ruling directly contradicted the holding in Pfizer. ${ }^{167}$ The Medinol court explained that the independent auditor and Boston Scientific do not share common interests because "as has become crystal clear in the face of the many accounting scandals that have arisen as of late, in order for auditors to properly do their job, they must not share common interests with the company they audit." 168 Instead, "good auditing requires adversarial tension between the auditor and the client." "169

The diametrically opposed holdings in Pfizer and Medinol exhibit how attorneys and accountants should be anything but confident that attorneys' responses to audit legal letters will be protected under the work product doctrine, depending on what theory the plaintiff pursues in challenging the privilege. Moreover, since the case law indicates the attorney-client privilege will not likely shield a lawyer's response to a CPA's inquiry letter, lawyers must remain reticent about disclosing too much; and accountants will continue to be frustrated by receiving too little. Part IV of this Note attempts to solve this persistent problem.

\section{Proposed SOLUTIONS}

As Parts I-III of this Note have illustrated, the current landscape offers very little clarity to legal practitioners who must decide how much detail they should provide in response to audit inquiries. Not only is this a problem for lawyers and their clients, but it is also a quandary for public accountants and the users of the financial statements that CPAs audit. Implementing the following changes would go a long way toward alleviating the current lack of clarity lawyers and accountants face today when addressing audit inquiry letters.

162. Medinol, Ltd. v. Boston Scientific Corp., 214 F.R.D. 113, 114 (S.D.N.Y. 2002).

163. Id.

164. Id.

165. Id.

166. Id. at 117 .

167. Id.

168. Id. at 116 .

169. Id. 


\section{A. Adopt an Accountant-Client Privilege Law on a Federal Level}

A federal accountant-client privilege is the "best assurance of open and honest communication[] between auditors and their clients." ${ }^{170}$ An accountantclient privilege would authorize a client to communicate with her accountant confidentially regarding interactions and information discussed between a client and her attorney. ${ }^{171}$ Additionally, an accountant-client privilege would allow a lawyer to communicate with a client's accountant. ${ }^{172}$ "The attorney, in essence, would be acting as the client's agent or representative in communicating confidential information to the accountant, and the statutory accountant-client privilege would protect this information as privileged." 173

An accountant-client privilege should be adopted on a federal level because enacting an accountant-client privilege would spur honest and uninhibited communication among clients and their CPAs and lawyers, providing an environment where professional advice would be based on the most complete information, "free from the consequences or the apprehension of disclosure."174 The necessity of such a doctrine is clear. Without it, if the attorney gives confidential legal analysis to the accountants, this information becomes discoverable in the event of a lawsuit. ${ }^{175}$

Currently, the federal courts and most states fail to recognize an accountantclient privilege. ${ }^{176}$ In fact, "[o]nly fifteen states have any such statute and, of those, only seven have expressly extended the privilege to independent auditors by statute or judicial ruling." 177

170. Allison Dabbs Garrett, Auditor Whistle Blowing: The Financial Fraud Detection and Disclosure Act, 17 Seton Hall Legis. J. 91, 119-20 (1993).

171. Michael W. Loudenslager, Cover Me: The Effects of Attorney-Accountant Multidisciplinary Practice on the Protections of the Attorney-Client Privilege, 53 BAYLOR L. REV. 33, 76-77 (2001).

172. Id

173. Id.

174. Neusteter v. Dist. Court of Denver, 675 P.2d 1, 5 (Colo. 1984).

175. See supra Part III.

176. Melissa D. Shalit, Audit Inquiry Letters and Discovery: Protection Based on Compulsion, 15 CARDOZo L. REV. 1263, 1304 (1994).

177. Latham \& Watkins LLP, The Auditor's Need for Its Client's Detailed Information vs. The Client's Need to Preserve the Attorney-Client Privilege and Work Product Protection: The Debate, The Problems, and Proposed Solutions 10 n.29 (ABA Section of Business Law-Audit Response Letters in the New Environment, Nov. 19, 2004), http://apps.americanbar.org/buslaw/newsletter/ 0039/materials/pp3.pdf[https://perma.cc/K2BF-67JY]. There are seven states that have specifically extended the accountant-client privilege to independent auditors: Colorado, Georgia, Illinois, Kansas, Maryland, Michigan, and New Mexico. Susan Hackett, Pragmatic Practices for Protecting Privilege, Ass'N CORP. Couns. 15 n.39 (Oct. 23, 2006), http://www.acc.com/vl/public/Article/ loader.cfm?csModule=security/getfile\&pageid=15983\&recorded $=1$ [https://perma.cc/2H36-TL9P]. In addition, eight other states recognize some variety of accountant-client privilege: Arizona, Florida, Idaho, Indiana, Louisiana, Missouri, Pennsylvania, and Tennessee. Id. 
Specifically, Michigan's current accountant-client privilege should be adopted on a federal level:

Except by written permission of the client or the heir, successor, or personal representative of the client to whom the information pertains, a licensee, or a person employed by a licensee, shall not disclose or divulge and shall not be required to disclose or divulge information relative to and in connection with an examination or audit of, or report on, books, records, or accounts that the licensee or a person employed by the licensee was employed to make. Except as otherwise provided in this section, the information derived from or as the result of professional service rendered by a certified public accountant is confidential and privileged. ${ }^{178}$

This accountant-client privilege allows: (1) a CPA to disclose otherwise confidential and privileged information to defend himself in a court action or administrative hearing when his "professional competence has been challenged in a court of law or before an administrative agency"179; (2) information to be disclosed "in the course of practice monitoring programs and ethical investigations conducted by a licensed certified public accountant"180; and (3) a CPA to disclose otherwise privileged information to government or law enforcement officers when the CPA "has knowledge that forms a reasonable basis to believe that a client has committed a violation of federal or state law or a local governmental ordinance." 181

Michigan's accountant-client law is superior to other states' statutes because Michigan's statute gives the client the right to exercise the accountant-client privilege rather than allowing only the accountant to assert the privilege. ${ }^{182}$ Additionally, Michigan's statute is preferable to other state accountant-client statutes because it allows the privilege to be maintained even if a subpoena in a court proceeding demands an accountant to turnover certain accountant-client communications. ${ }^{183}$ Arming clients with an accountant-client privilege strong

178. МiсH. СомP. LAWS § 339.732(1) (2016).

179. Id. $\S 339.732(2)(\mathrm{a})$.

180. Id. $\S 339.732(2)(\mathrm{b})$

181. Id. $\S 339.732(2)(\mathrm{c})$.

182. See, e.g., W. Emp'rs Ins. Co. v. Merit Ins. Co., 492 F. Supp. 53, 55 (N.D. Ill. 1979) (holding the Illinois accountant-client privilege "inures only to the accountant" and "cannot be raised or claimed by the client").

183. These fifteen state statutes require accountants to disclose any communications with their clients pursuant to a subpoena: ALASKa Stat. § 08.04.662 (2016); ARIZ. ReV. StAT. AnN. § 32-749 (2016); Conn. Gen. Stat. § 20-281j (2016); Kan. Stat. Ann. § 1-401 (2016); Ky. Rev. Stat. Ann. § 325.440 (2016); La. Rev. Stat. Ann. § 37:86 (2016); Me. Rev. Stat. tit. 32, § 12279 (2016); Mass. Gen. Laws ch. 112, § 87E (2016); Miss. Code AnN. § 73-33-16 (2016); Mont. Code Ann. § 37-50-402 (2016); N.D. Cent. Code AnN. § 43-02.2-16 (2016); R.I. Gen. Laws § 5-3.1-23 (2016); Tex. Occ. Code AnN. § 901.457 (2016); Vt. Stat. AnN. tit. 26, § 82 (2016); WASH. ReV. CODE ANN. § 18.04.405 (2016). Loudenslager, supra note 171, at 85 n.162. 
enough to uphold protection in the face of court-compelled disclosure would largely eradicate the problems with which this Note is most concerned.

Attorneys would feel secure in providing accountants with highly detailed analyses of any pending or threatened litigation without the threat that their opinions would be subject to discovery in pending or future litigation if their evaluation turned out to be inaccurate. Furthermore, promulgating a federal accountant-client privilege would help assure accountants that they were receiving an accurate picture of a lawyer's estimation of potential liabilities from pending or threatened claims. Finally, investors and lenders would be more confident they were receiving the most transparent information regarding a company's contingent liabilities, which would likely instill increased investor and overall public confidence in the nation's stock market.

\section{B. ABA and FASB Should Issue Co-Authored Practice Guides}

While adopting a federal accountant-client privilege is the preferred solution to the current dilemma attorneys and accountants face in regard to audit inquiry letters, drafting comprehensive legislation could prove a lengthy and perhaps contentious process. ${ }^{184}$ Until Congress adopts a federal accountant-client privilege, the ABA and FASB should co-author practice guides that provide direction to legal and accounting professionals focused on how to author and respond to audit request letters.

The ABA Statement was last updated more than forty years ago. ${ }^{185}$ Since then, there has been a plethora of pertinent cases and new laws that have been passed. Most significantly is the passage of SOX and the fact that SOX "makes it a crime to mislead an independent accountant in a way that causes a company's financial statements to be misleading." ${ }^{186}$ Equally influential is the SOX provision requiring attorneys to report any "material violation of securities law or breach of fiduciary duty or similar violation by the company or any agent thereof." 187

1. The Need for Two Separate Guides.-The ABA and FASB should coauthor two separate guides. One guide should specifically focus on how to respond to audit requests from publicly held clients and a second should concentrate on responding to audit requests from clients within the private arena. There should be two distinct pronouncements because SEC Rule 13b2-2(b)(1)

184. Two of the stronger arguments against the expansion of privileges are: (1) "privileges prevent the use of highly relevant evidence"; and (2) attorneys should have an attorney-client privilege and accountants should not have an accountant-client privilege because an attorney's role is to be "a confidential advisor with a duty of undivided loyalty to her client" while an accountant owes a duty not only to a client, but also to "government agencies regulating the client's industry, the client's creditors, and the client's investors." Emily Jones, Keeping Client Confidences: Attorney-Client Privilege and Work Product Doctrine in Light of United States v. Adlman, 18 PACE L. REV. 419, 429-30 (1998).

185. ABA Statement of Policy, supra note 37.

186. Johnson, supra note 42 , at 47.

187. $I d$. 
and a majority of SOX's provisions apply only to companies, private or public, that file financial statements with the SEC. Creating two separate guides would fall in line with the way the accounting governing body is moving; the FASB established the Private Company Council ("PCC") in May $2012^{188}$ in order to provide private companies with their own accounting standards that removed or modified broader requirements that were irrelevant or counterproductive to private companies. ${ }^{189}$

In writing the guide for responding to audit requests from publicly traded clients, the ABA and FASB should seek guidance from the SEC and the PCAOB in helping give best practices for authoring and responding to legal letters. Utilizing assistance from the SEC will help remove uncertainties attorneys currently face regarding whether the SEC might pursue a case against a lawyer whose audit letter response follows the ABA Statement's guidance but still yields an SEC opinion that the response misleads the auditor and violates SEC Rule $13 \mathrm{~b} 2-2 .{ }^{190}$ Reaching out to the PCAOB will provide clarity to CPAs regarding the level of detail public accountants should request and require of attorneys before issuing an unmodified opinion. Overall, unifying financial regulators with representatives from the accounting and legal spheres would help produce a comprehensive guide that integrates multiple interests and delivers much-needed clarity.

In sculpting the guide that focuses on responding to audit requests from nonpublic clients, the ABA and the FASB should pursue input from the PCC. In drafting the guidelines for sending and responding to audit legal letters, these three organizations should form their recommendations in a manner that recognizes that "the information that users of private company financial statements consider decision-useful" differs from the type of information users of public company financial statements generally require. ${ }^{191}$ Users of the financial

188. Private Company Council (PCC), FASB, http://www.fasb.org/cs/ContentServer?c= Page \& pagename $=$ FASB $\% 2 F$ Page $\% 2 F S e c t i o n P a g e \& c i d=1351027243391 \quad$ [perma.cc $/ Z 4 R X-$ MGAU] (last visited Mar. 26, 2017).

189. Robert Shaftoe, Auditing Standards for Private Companies, CHRON, http://smallbusiness.chron.com/auditing-standards-private-companies-77666.html [http://perma.cc/PUZ5-Z9Z9] (last visited Mar. 26, 2017).

190. Former SEC General Counsel Simon Lorne's comments on the impact SOX might have on SEC rules regarding improper influence on conduct of audits: "[T] he revised Rule 13b2-2 raises the question whether a response to auditors in careful consistency with [the ABA Statement] might not, under at least some circumstances, be viewed as misleading to the auditors and hence violative." Simon M. Lorne, An Issue-Annotated Version of the SOX Rules for Lawyer Conduct [A Work-in-Process], in Pre-Conference Briefing to the Institute on SeCURIties Regulation (37th Annual): Gatekeepers Under Scrutiny: What Attorneys, Accountants and Directors Need to Know Now 585, 610 (Practising Law Inst. ed., 2005).

191. Blue-Ribbon Panel on Standard Setting for Private Companies, Report to the Board of Trustees of the Financial Accounting Foundation 1 (Jan. 2011), http://www.aicpa.org/interestareas/ frc/accountingfinancialreporting/pcfr/downloadabledocuments/blue_ribbon_panel_report.pdf [https://perma.cc/Q9M8-7XKK]. 
statements of private companies generally include lenders, credit-rating agencies, business owners, and regulators. ${ }^{192}$ Because the scope of users of private company financial statements is exponentially smaller than the scope of users of public financial statements and since private companies are subject to fewer regulations, ${ }^{193}$ the ABA, FASB, and PCC might advise CPAs to request and attorneys to provide fewer details in audit inquiry letters.

2. Requirements to be Addressed in Both Guides.-While there is a variety of issues that should be separately addressed in the proposed public company and private company guides, there are also changes that should be consistent in both guides. Each should bridge the gap that currently exists regarding determining the likelihood that a particular litigation matter might result in a loss that should be accrued for or disclosed in the notes to the financial statements. As described in Part II of this Note, the ABA's Statement contains a higher bar than the FASB when it comes to degree of certainty required regarding the outcome of a case before disclosing to the auditors that an unfavorable outcome might occur. ${ }^{194}$

The proposed practice guides should include consistent and quantifiable definitions for the key descriptors of likelihood, including the words "probable," "reasonably possible," and "remote." 195 For instance, the guides could set out percentage-based definitions. As one commentator posited, "specify that a probable outcome corresponds with an $80-99 \%$ chance of occurrence, a reasonably possible outcome would have anywhere from $21-79 \%$ odds, and a remote outcome would have a $0-20 \%$ probability." 196 Coming up with uniform terminology for audit inquiry letters and responses would provide a consistent foundation upon which accountants, attorneys, and financial statement users could "base their assessments of a company's performance and investment value." 197

Additionally, quantifying the likelihood that a particular contingent liability will occur in terms of a percentage range would also allow lawyers and auditors to better determine the accuracy of their estimations compared to the actual losses that end up occurring. For example, suppose an auditor asks a lawyer to provide an evaluation of the likelihood of an unfavorable outcome in several pending lawsuits against an attorney's client. There are ten cases currently being litigated

192. Id. at 10 .

193. For example, SEC Rule 13b2-2 is only applicable to audits of issuers of financial statements "that are required to be filed with the [SEC]." Securities Exchange Act of 1934, 17 C.F.R. $\S 240.13 \mathrm{~b} 2-2$ (2016).

194. Attorney Responses to Audit Letters, supra note 106, at 875.

195. Samantha Nicole Kunz, From Legally Confidential to Financially Confident: Resolving the Tension Between Lawyers and Auditors over Contingent Liability Disclosure 59 (Apr. 27, 2015) (unpublished B.A. thesis, Claremont McKenna College), http://scholarship.claremont. $\mathrm{edu} /$ cgi/viewcontent.cgi?article $=2130 \&$ context $=$ cmc_theses [perma.cc/N25T-DNWK] (describing a proposal that the FASB establish a new system for the measurement of probability for determining whether a contingent liability requires disclosure).

196. Id.

197. Id. at 61 . 
against the client with a total maximum exposure of $\$ 100$ million. If the lawyer responds to the auditor by saying all ten of the cases have only a remote possibility of an unfavorable outcome, the accrual may properly be placed in the zero to $\$ 20$ million range under these guidelines. Presently, no such estimate could be as precisely made.

A similar concept should be applied in defining whether the amount of a particular potential litigation liability can be "reasonably estimated." As Part II of this Note explains, lawyers too often stymie accountants' attempts to have lawyers estimate the amount or range of potential loss by asserting it is impossible to reasonably estimate the contingent liability amount. ${ }^{198}$ The effect of this practice is that accountants have a more difficult time accruing an accurate expense amount, resulting in income statements which might overstate net profit figures.

The ABA/FASB practice guides should recognize a CPA's legitimate interest in producing financial statements with complete and accurate information ${ }^{199}$ while also respecting attorneys' understandable hesitancy to furnish judgments about the outcome of lawsuits because of inherent uncertainties surrounding such estimates and worries about destroying client confidentiality. ${ }^{200}$ The ABA and FASB should describe in these practice guides that it is appropriate for a lawyer to provide an estimate of the amount or range of a potential loss if the attorney believes there is less than a X\% probability that the estimate is inaccurate. ${ }^{201}$ The determination of what number the " $X$ " should be in the preceding sentence should be a compromise between the ABA and the FASB. Quantifying the percentage to a number with which both professional organizations could live, would add much-needed consistency and clarity to a standard that is currently inconsistent between accountants and lawyers and which utilizes nebulous, ambiguous terminology. ${ }^{202}$

\section{CONCLUSION}

Because the auditor's duty is to the public and the readers of the client's

198. Attorney Responses to Audit Letters, supra note 106, at 875.

199. Koprowski et al., supra note 29, at 443 (describing investor and regulator frustrations with inadequate disclosure and liability accrual for pending litigation).

200. Id. at 448 (describing the attorney-client privilege can be waived if privileged information is provided to a third party).

201. This suggested wording is derived from the current ABA Statement, which says: "[I]t is appropriate for the lawyer to provide an estimate of the amount or range of potential loss (if the outcome should be unfavorable) only if he believes that the probability of inaccuracy of the estimate of the amount or range of potential loss is slight." ABA Statement of Policy, supra note 37, at para. 5 .

202. For example, currently the ABA Statement suggests that attorneys should not quantify the amount or range of potential loss unless the "probability of inaccuracy of the [loss] estimate . .. is slight." Id. However, the ABA Statement does not define precisely what "slight" means in this context. 
financial statements while the attorney's duty is to the client and the client's management, there is unavoidable tension between these duties and corresponding professional standards of care. ${ }^{203}$ The gap in accountants' and attorneys' duties is apparent in the guidance provided to each respective group by its representative body. Attorneys' ABA Statement focuses on maintaining attorney-client confidentiality and focuses on disclosing as little information about pending litigation as possible. ${ }^{204}$ Accountants' FASB Accounting Standards Codification focuses on obtaining the greatest amount of transparency possible by demanding attorneys provide specific and detailed information regarding pending litigation and possible loss contingencies. ${ }^{205}$

Before the large and well-publicized accounting scandals of the early $2000 \mathrm{~s}$, like Enron and WorldCom, there seemed to be less contention with regard to the sufficiency and level of detail of lawyers' responses to audit inquiry letters. However, after these scandals and after the advent of SOX and new SEC guidelines that punish those who mislead public accountants in their financial statement audits, there is a higher level of scrutiny and corresponding risk with respect to the type of information lawyers send about pending litigation and the potential outcomes of those lawsuits.

With changing expectations placed on attorneys and their responsibilities to provide more detailed information to public accountants, the more than fortyyear-old ABA Statement needs to be updated and revamped as well. ${ }^{206}$ There also should be an accountant-client privilege added on a nationwide scale that allows attorneys to disclose more detailed information to accountants regarding upcoming litigation without facing the possibility that this information will be discoverable in future litigation. ${ }^{207}$

203. See supra Part I.

204. See $i d$.

205. See ASC § 450-20 (2010).

206. See supra Part IV.

207. See supra Part IV.A. 